\title{
PENGEMBANGAN BAHAN AJAR DENGAN MODEL GROUP INVESTIGATION (GI) PADA MATERI BANGUN DATAR SEGIEMPAT
}

\author{
Arbayanti $^{1}$, Aulia Sthephani ${ }^{2}$, Abdurrahman $^{3}$, Endang Istikomah $^{4}$ \\ ${ }^{1}$ Universitas Islam Riau, ${ }^{2}$ Universitas Islam Riau, ${ }^{3}$ Universitas Islam \\ Riau, ${ }^{4}$ Universitas Islam Riau \\ arbayanti30@gmail.com, sthephania@edu.uir.ac.id, \\ abdurrahman@edu.uir.ac.id, endangistikomah@edu.uir.ac.id
}

\begin{abstract}
ABSTRAK
Penelitian ini bertujuan untuk menghasilkan suatu produk berupa Rencana Pelaksanaan Pembelajaran (RPP) dan Lembar Kerja Peserta Didik (LKPD) yang valid dengan menggunakan model pembelajaran Group Investigation (GI) pada materi bangun datar segiempat. Hal ini dasarkan oleh masih rendahnya kemampuan guru dalam menyusun perangkat pembelajaran berupa Rencana Pelaksanaan Pembelajaran dan Lembar Kerja Peserta Didik. Metode penelitian yang digunakan adalah Research and Development (R\&D) yang langkah-langkahnya telah dimodifikasi yaitu: (1) Potensi dan Masalah; (2) Pengumpulan Data; (3) Desain produk; (4) Validasi Desain; (5) Revisi Desain; dan (6) Produk Akhir. Instrumen pengumpulan data pada penelitian ini adalah lembar validasi RPP dan lembar validasi LKPD. Teknik pengumpulan data yang digunakan adalah data validasi dari 4 validator yang terdiri dari 2 orang Dosen Matematika FKIP UIR dan 2 orang Guru Matematika SMP PGRI Pekanbaru. Teknik analisis yang digunakan adalah teknik analisis data validasi. Hasil penelitian pengembangan bahan ajar ini validitas RPP adalah 91,94\% dan validitas LKPD adalah 91,14\% yang mana memenuhi kriteria sangat valid. Maka berdasarkan hasil penelitian ini diperoleh bahan ajar dengan kriteria sangat valid atau dapat digunakan tanpa revisi.
\end{abstract}

Kata Kunci: Group Investigation (GI), Bahan ajar.

\begin{abstract}
This research aims to produce a learning device in terms of lesson plan and student worksheet which is valid with Group Investigation (GI) in quadrilateral. It is based on the still low ability of teachers in bulding learning devices in the form of learning plan and worksheets. The method of this research is Research and Development (R\&D) which steps have been modified. The steps are: (1) Potency and Problem; (2) Collected Data; (3) Design Product; (4) Design Validation; (5) Design Revision; (6) Product Final. Data collection instruments are validation papers for student worksheets. Data collection technique is data validation from 4 validators consisting of 2 Lecturer Mathematics Department Faculty Teacher Training and Education University Islamic of Riau and 2 teacher Junior High School PGRI of Pekanbaru. Data analysis technique is analysis validation. The result of this research validity of lesson plan is $91,14 \%$ and validity of student worksheet is $91,14 \%$ which satisfied a very valid category. Based on this research I obtained a learning device with a very valid category and proper to use without revision.
\end{abstract}

Keywords: Group Investigation (GI), Development, Learn Plan.

\section{PENDAHULUAN}

Matematika merupakan salah satu bidang ilmu pengetahuan yang berperan sangat penting dalam menunjang kemajuan ilmu pengetahuan dan teknologi saat ini. Dalam ini 
membuat pemerintah yang merupakan penyelenggara pendidikan di Indonesia selalu berupaya untuk meningkatkan mutu dan kualitas pendidikan khususnya dalam pembelajaran matematika. Menurut Suripah dan Sthephani (2017: 414) di jenjang perguruan tinggi mata kuliah yang berhubungan dengan matematika tidak hanya mencapai tujuan untuk mencerdaskan saja, tetapi juga memiliki tujuan dan kemampuan untuk membentuk sikap dan kebiasaan berpikir logis, kritis, analitis, sistematis, inovatif, kerja cepat, tekun, dan kreatif, serta memiliki kemampuan saling bekerja sama satu sama lain dan bertanggung jawab.

Dalam upaya untuk meningkatkan kualitas pembelajaran matematika dapat dimulai dari proses belajar dan pembelajaran matematika di dalam kelas. Untuk itu diperlukan sarana penunjang dalam proses pembelajaran seperti perangkat pembelajaran yang dapat memenuhi kebutuhan belajar peserta didik yang sesuai dengan pendekatan pembelajaran yang digunakan nantinya. Hal ini dilakukan agar peserta didik mampu belajar secara aktif di dalam kelas. Bahan ajar yang baik juga memudahkan guru dalam mengelola proses pembelajaran dan melakukan penilaian, untuk itu hendaknya setiap guru membuat dan merencanakan perangkat pembelajaran sebaik-baiknya. Pentingnya pengembangan perangkat pembelajaran tertuang dalam Peraturan Pemerintah Republik Indonesia Nomor 32 Tahun 2013 tentang standar nasional pendidikan pasal 20 yang berbunyi "Perencanaan pembelajaran merupakan penyusunan rencana pelaksanaan pembelajaran untuk setiap muatan pembelajaran".

Menurut Alvionita, Abdurrahman, \& Herlina (2019: 49) perangkat pembelajaran matematika berupa silabus, RPP, dan LKPD merupakan salah satu wujud persiapan yang dilakukan oleh guru sebelum melakukan proses pembelajaran di dalam kelas.

Berdasarkan hasil wawancara yang peneliti lakukan pada tanggal 28 Januari 2020 dengan guru matematika kelas VII SMP PGRI Pekanbaru diperoleh informasi bahwa:

1. Guru telah menyusun Rencana Pelaksanaan Pembelajaran (RPP) sesuai dengan kurikulum 2013 yang ditetapkan oleh pemerintah dan dalam kegiatan pembelajarannya telah menerapkan pendekatan saintifik (5 M), tetapi dalam penyusunan RPP yang dibuat oleh guru jarang menggunakan model-model atau metode pembelajaran matematika dengan alasan terlalu banyak memakan waktu.

2. Guru belum mencoba mengembangkan RPP dengan menambahkan metode atau model-model pembelajaran.

3. Lembar Kerja Peserta Didik (LKPD) yang dibuat oleh guru hanya berupa latihanlatihan soal saja dan tidak mengandung masalah nyata yang dialami peserta didik. 
Dari hasil wawancara di atas, tampak jelas bahwa guru masih mengalami kesulitan dalam mengembangkan RPP dan LKPD yang merupakan perangkat pembelajaran berdasarkan kurikulum 2013. Walaupun demikian, guru menyadari bahwa perangkat pembelajaran yang dibuatnya masih terdapat kekurangan. Dalam proses penyempurnaan kurikulum 2013, pemerintah sebagai penyelenggara pendidikan di Indonesia terus melakukan perbaikan, dan mengembangkan serta melaksanakannya di setiap sekolah agar mutu dan kualitas pendidikan lebih baik. Menurut Anggreini, Zulkarnain, \& Ariawan (2019: 35) menyatakan bahwa terdapat kesulitan bagi guru dalam menerapkan kurikulum dikarenakan adanya keterbatasan pengetahuan dan sumber belajar yg terkait dengan konsep pembelajaran dan penilaian yang telah ditetapkan. Supaya proses pembelajaran menjadi lebih optimal dan interaktif maka perlu adanya perangkat pembelajaran yang mendukung keterlaksanaan yaitu Rencana Pelaksanaan Pembelajaran (RPP) dan Lembar Kerja Peserta Didik (LKPD).

Menurut Ariawan dan Putri (2020: 294) perangkat pembelajaran merupakan sekumpulan sumber belajar berupa media atau sarana yang mana digunakan oleh guru dan peserta didik dalam melakukan kegiatan pembelajaran agar dapat berjalan lancar, efektif dan efisien. Dalam menunjang pencapaian keberhasilan kegiatan pembelajaran, perangkat pembelajaran harus dimiliki oleh seorang guru. Untuk itu setiap guru dituntut untuk menyiapkan dan merencanakan perangkat pembelajaran sebaik-baiknya guna mencapai keberhasilan dalam melakukan kegiatan pembelajaran secara optimal di dalam kelas. Menurut Trianto (2012: 96) bahwa silabus merupakan rencana pembelajaran pada suatu dan/atau kelompok mata pelajaran atau tema tertentu yang mencakup Standar Kompetensi, Kompetensi Dasar, materi/pokok pembelajaran, kegiatan pembelajaran, indikator, pencapaian kompetensi untuk penilaian, alokasi waktu, dan sumber belajar.

Menurut Komalasari (2014: 193) yang menyatakan bahwa RPP merupakan penjabaran dari silabus yang mana langkah-langkah sebelumnya telah disusun, di dalam RPP mencerminkan kegiatan-kegiatan yang akan dilakukan oleh guru dan dan peserta didik untuk mencapai kompetensi dan tujuan pembelajaran yang telah ditetapkan. Menurut Iqbal (2017:32) LKPD merupakan suatu pedoman bagi peserta didik yang mana telah disusun dan didesain sedemikian rupa sehingga memberikan kesempatan kepada peserta didik untuk memperluas pemahaman materi yang menjadi tujuan pembelajaran. Pedoman tersebut berisi kegiatan-kegiatan yang terarah dan aktif.

Melihat uraian yang ada di atas peneliti merasa perlu mengembangkn suatu 
perangkat berupa Rencana Pelaksanaan Pembelajaran (RPP) dan Lembar Kerja Peserta Didik (LKPD) agar proses pembelajaran menjadi lebih efektif. yang mana sesuai dengan pendapat dari Putri, Setyawan, \& Effendi (2019: 80) dengan penggunaan LKPD saat pembelajaran dapat memberikan kesempatan penuh kepada peserta didik untuk mengungkapkan kemampuan, dan keterampilan yang ada dalam diri peserta didik untuk berbuat sendiri dalam mengembangkan proses berpikirnya melalui mencari, menyelidiki, menebak, bahkan menalar. Oleh karena itu diperlukan suatu terobosan baru yang menuntut kemampuan guru untuk dapat menciptakan dan merencanakan suatu perangkat pembelajaran yang mampu memotivasi sikap peserta didik dan mampu mendorong peserta didik agar mampu menyelesaikan persoalan-persoalan dalam pembelajaran matematika berupa perangkat pembelajaran yaitu Rencana Pelaksanaan Pembelajaran (RPP) dengan memasukkan model pembelajaran yang menyenangkan dan menarik perhatian peserta didik. Menurut Sadat, Harisuddin, \& Oktavian (2020: 161) mengatakan bahwa dewasa ini tenaga pendidik dituntut untuk lebih kreatif dan inovatif dalam menemukan dan menentukan pedekatan/metode mengajar yang sesuai dengan materi yang akan diajarkan sehingga tujuan pembelajaran yang diinginkan tercapai.

Salah satu model pembelajaran yang menitikberatkan kemampuan peserta didik dalam mengerjakan sesuatu secara berkelompok dan kemampuan saling berkomunikasi yang baik terhadap sesama teman sekelas adalah dengan model pembelajaran Group Investigation (GI). Maka dari itu peneliti mengambil model pembelajaran Group Investigation (GI) yang diharapkan dapat memotivasi peserta didik dan mampu mendorong peserta didik untuk kreatif dan inovatif. selain itu, model pembelajaran Group Investigation (GI) ini mampu menciptakan suasana belajar aktif dan mampu meningkatkan hasil belajar siswa mencapai taraf ketuntasan belajar secara klasikal. Segiempat merupakan salah satu materi geometri yang cukup luas aplikasinya baik dalam kehidupan sehari-hari maupun keterkaitannya dengan materi matematika yang lain dan dengan bidang studi yang lain pula. Materi segiempat dapat diaplikasikan dalam kehidupan sehari-hari seperti menghitung luas kebun yang berbentuk persegi, menghitung keliling kebun danlain-lain. Dalam penelitian yang dilakukan, Dari penelitian yang dilakukan oleh Hartono dan Pramukantoro tahun 2013 mengenai pengembangan perangkat pembelajaran dengan model Group Investigation (GI). disimpulkan bahwa perangkat pembelajaran dengan menggunakan model pembelajaran Group Investigation (GI) baik/layak atau valid digunakan sebagai pembelajaran. Dan penelitian yang dilakukan oleh Septiawan dan Sondang tahun 2013. Mengenai 
pengembangan perangkat pembelajaran dengan model Group Investigation (GI) masuk kedalam kategori layak atau baik untuk digunakan dalam proses pembelajaran.

Berdasarkan uraian di atas maka dikembangkan perangkat pembelajaran dengan model Group Investigation (GI) pada materi bangun datar Segiempat dengan kriteria yang valid. Rumusan masalah dalam pengembangan ini adalah (1) Bagaimanakah proses pengembangan perangkat pembelajaran dengan menggunakan model Group Investigation (GI) pada bangun datar segiempat?, dan (2) Bagaimanakah hasil validitas pengembangan perangkat pembelajaran dengan menggunakan model Group Investigation (GI) pada bangun datar segiempat? dan Tujuan penelitian yang ingin dicapai dalam penelitian ini adalah (1) Untuk mengetahui proses pengembangan perangkat pembelajaran dengan menggunakan model pembelajaran Group Investigation (GI) pada materi bangun datar segiempat, dan (2) Untuk mengetahui hasil validitas pengembangan perangkat pembelajaran dengan menggunakan model pembelajaran Group Investigation (GI) pada materi bangun datar segiempat.

\section{METODE PENELITIAN}

Penelitian ini merupakan penelitian pengembangan dengan istilah Research and Development (R\&D). Menurut Borg dan Gall (dalam Setyosari, 2013: 222) menyatakan bahwa "Penelitian pengembangan adalah suatu proses yang dipakai untuk mengembangkan dan memvalidasi produk penelitian . penelitian ini mengikuti suatu langkah-langkah secara siklus. Langkah penelitian atau proses pengembangan terdiri atas kajian tentang temuan penelitian produk yang akan dikembangkan, mengembangkan produk berdasarkan temuantemuan tersebut, melakukan uji coba lapangan sesuai latar dari mana produk tersebut dipakai dan melakukan revisi terhadap hasil uji lapangan.”

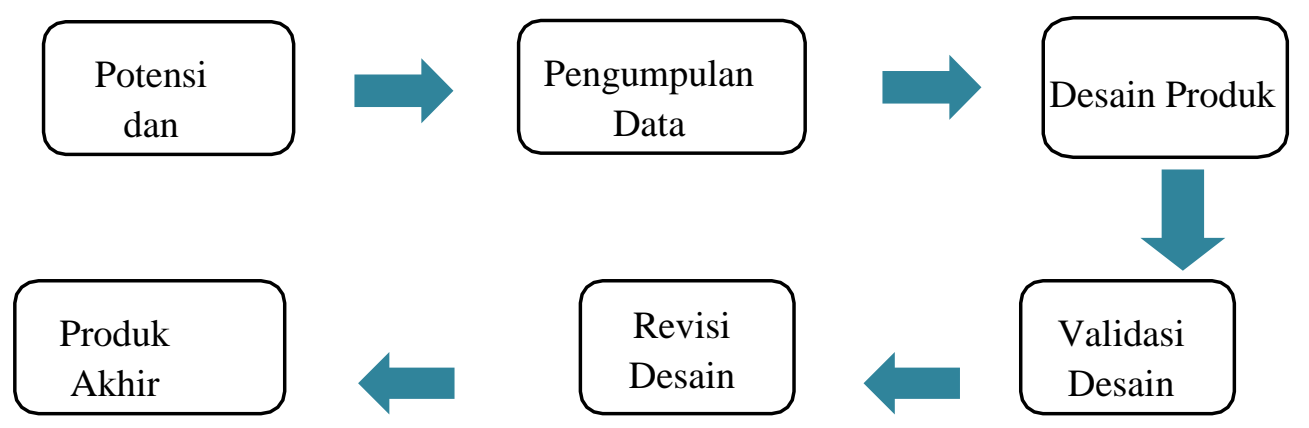

Gambar 1. Modifikasi Langkah-langkah Pengembangan Research and Development (R\&D) pada Perangkat Pembelajaran 
Penelitian pengembangan ini dikembangkan dengan model penelitian Research and Development (R\&D) yang mana langkah-langkahnya sudah peneliti modifikasi sesuai kebutuhan penelitian. Adapun langkah-langkah yang digunakan, yaitu: 1) Tahapan Potensi dan Masalah, 2) Tahapan Pengumpulan Data, 3) Tahapan Desain Produk, 4) Tahapan Validasi Desain, dan 5) Tahapan Revisi Desain. Produk yang dihasilkan dari penelitian ini adalah perangkat pembelajaran yang terdiri dari Rencana Pelaksanaan Pembelajaran (RPP) dan Lembar Kerja Peserta Didik (LKPD).

Dikarenakan hanya pada tahap validasi Maka waktu dan tempat pelaksanaan penelitian yang berlokasi di dua tempat yakni, di Program Studi Pendidikan Matematika Fakultas Keguruan dan Ilmu Pendidikan gedung A Universitas Islam Riau, Jl. Kaharuddin Nasution No 113 Pekanbaru Riau dan di SMP PGRI Pekanbaru yang terletak di Jalan Brigjen Katamso No. 42, Tangkerang Utara, Kec. Bukit Raya, Kota Pekanbaru, Riau. Dalam penelitian ini yang menjadi objek penelitian pengembangan ini adalah Rencana Pelaksanaan Pembelajaran (RPP) dan Lembar Kerja Peserta Didik (LKPD). Instrumen pengumpulan data yang digunakan merupakan lembar validasi. Teknik pengumpulan data adalah data validasi dari tim ahli dosen FKIP Matematika dan guru Matematika SMP PGRI Pekanbaru, dalam penelitian ini, data yang digunakan adalah berupa hasil uji coba berupa lembar validasi. Produk yang dihasilkan ditunjukkan kepada ahli, setelah menelaah produk, tim ahli mengisi angket validasi yang diberikan. Data yang diperoleh adalah hasil dari angket validasi yang telah diisi oleh tim ahli.

\section{HASIL PENELITIAN DAN PEMBAHASAN}

Hasil penelitian pada penelitian pengembangan perangkat pembelajaran dengan model Group Investigation (GI) pada materi bangun datar yang dilakukan melalui langkahlangkah sebagai berikut: (1) Tahap potensi dan masalah teknik yang dilakukan adalah wawancara dengan guru Matematika SMP PGRI Pekanbaru diperoleh informasi bahwa dalam pembelajaran sekolah telah menggunakan kurikulum 2013 dengan pendekatan saintifik. Pada RPP dengan kurikulum 2013 yang digunakan oleh guru, tidaklah dibuat dan disusun langsung oleh guru itu sendiri melainkan mengambil dari sumber lain seperti internet dan dari dinas pendidikan. Sedangkan permasalahan pada LKPD yang dibuat oleh guru hanya memuat kumpulan soal-soal saja. Akibatnya peserta didik tidak bersemangat dan cenderung malas untuk mengerjakan soal tersebut dan pembelajaran yang dialami menjadi tidak efektif. (2) Tahap pengumpulan data yang dikumpulkan berupa Silabus, Rencana Pelaksanaan Pembelajaran (RPP) yang digunakan oleh guru dan Lembar Kerja Peserta Didik 
(LKPD) yang digunakan oleh peserta didik. (3) tahap desain produk Desain produk dilakukan dengan membuat rancangan kesesuaian produk, Rencana Pelaksanaan Pembelajaran (RPP) dan Lembar Kerja Peserta Didik (LKPD). (4) Validasi desain dilakukan oleh tim ahli yaitu terdiri dari 2 orang dosen Matematika FKIP UIR dan 2 orang guru Matematika SMP PGRI Pekanbaru.

Tabel 1. Hasil Analisis Validasi RPP

\begin{tabular}{|c|c|c|c|c|c|c|}
\hline \multirow{2}{*}{ RPP } & \multicolumn{4}{|c|}{ Persentase Validasi (\%) } & \multirow{2}{*}{$\begin{array}{c}\text { Rata-rata } \\
(\%)\end{array}$} & \multirow{2}{*}{ Tingkat Validasi } \\
\hline & V1 & $\mathrm{V} 2$ & V3 & V4 & & \\
\hline RPP 1 & 87,50 & 92,50 & 88,75 & 98,75 & 91,87 & Sangat Valid \\
\hline RPP 2 & 87,50 & 92,50 & 88,75 & 98,75 & 91,87 & Sangat Valid \\
\hline RPP 3 & 87,50 & 92,50 & 90,00 & 98,75 & 92,18 & Sangat Valid \\
\hline RPP 4 & 87,50 & 92,50 & 88,75 & 98,75 & 91,87 & Sangat Valid \\
\hline \multicolumn{5}{|c|}{ Rata-rata Total } & 91,94 & Sangat Valid \\
\hline
\end{tabular}

Berdasarkan penilaian dari keempat validator iperoleh nilai rata-rata persentase validasi dari seluruh pertemuan adalah $91,94 \%$ yang masuk dalam kriteria sangat valid atau dapat digunakan tanpa revisi. yang mana hasil dari validasi perangkat pembelajaran berupa Rencana Pelaksanaan Pembelajaran (RPP) dengan menggunakan model Group Investigation (GI).

Tabel 2. Hasil Analisis Validasi LKPD

\begin{tabular}{|c|c|c|c|c|c|c|}
\hline \multirow{2}{*}{ LKPD } & \multicolumn{4}{|c|}{ Persentase Validasi (\%) } & \multirow{2}{*}{$\begin{array}{c}\text { Rata-rata } \\
(\%)\end{array}$} & \multirow{2}{*}{ Tingkat Validasi } \\
\hline & $\mathrm{V} 1$ & $\mathrm{~V} 2$ & V3 & $\mathrm{V} 4$ & & \\
\hline LKPD 1 & 93,75 & 83,33 & 91,66 & 95,83 & 91,14 & Sangat Valid \\
\hline LKPD 2 & 93,75 & 83,33 & 91,66 & 95,83 & 91,14 & Sangat Valid \\
\hline LKPD 3 & 93,75 & 83,33 & 91,66 & 95,83 & 91,14 & Sangat Valid \\
\hline \multirow[t]{2}{*}{ LKPD 4} & 93,75 & 83,33 & 91,66 & 95,83 & 91,14 & Sangat Valid \\
\hline & \multicolumn{4}{|c|}{ Rata-rata Total } & 91,14 & Sangat Valid \\
\hline
\end{tabular}

Berdasarkan penilaian dari keempat validator diperoleh nilai rata-rata persentase validasi dari seluruh pertemuan adalah $91,14 \%$ yang masuk dalam kriteria sangat valid atau dapat digunakan tanpa revisi. yang mana hasil dari validasi perangkat pembelajaran berupa Lembar Kerja Peserta Didik (LKPD) dengan menggunakan model Group Investigation (GI). Lalu pada tahap (5) Tahap revisi desain salah satunya adalah pada bagian langkah- langkah pembelajaran tambahkan metode yang digunakan dalam pembelajaran dan jabarkan alokasi waktu tiap-tiap poin. Kemudian persingkat lagi kata-kata pada bagian kegiatan pendahuluan. Kelemahan tersebut selanjutnya dicoba untuk dikurangi dengan cara memperbaiki desain, guna menyempurnakan desain. Lalu pada tahap akhir adalah (6) produk akhir dari penelitian ini berupa perangkat pembelajaran Rencana Pelaksanaan Pembelajaran (RPP) dan Lembar 
Kerja Peserta Didik (LKPD) dengan menggunakan model Group Investigation (GI) pada materi bangun datar segiempat yang telah direvisi berdasarkan saran dan masukan dari para validator.

Penelitian ini merupakan penelitian pengembangan. Penelitian ini mengembangkan perangkat pembelajaran dengan model Group Investigation (GI) pada materi bangun datar segiempat. Penelitian ini dilaksanakan pada semester genap tahun ajaran 2020/2021 di SMP PGRI Pekanbaru, namun penelitian ini tidak melakukan uji coba produk dan hanya sampai tahap uji validitas terhadap produk. Hal ini dikarenakan keadaan saat ini yang tidak memungkinkan untuk melakukan uji coba produk secara langsung karena sedang pandemi Covid-19 yang mengharuskan peserta didik untuk melakukan kegiatan belajar dari rumah atau daring. Penelitian pengembangan ini dikembangkan dengan model penelitian Research and Development (R\&D) yang mana langkah-langkahnya sudah peneliti modifikasi sesuai kebutuhan penelitian. Adapun langkah-langkah yang digunakan, yaitu: 1) Tahapan Potensi dan Masalah, 2) Tahapan Pengumpulan Data, 3) Tahapan Desain Produk, 4) Tahapan Validasi Desain, dan 5) Tahapan Revisi Desain. Produk yang dihasilkan dari penelitian ini adalah perangkat pembelajaran yang terdiri dari Rencana Pelaksanaan Pembelajaran (RPP) dan Lembar Kerja Peserta Didik (LKPD).

Setelah melakukan validasi perangkat pembelajaran matematika dengan mendapatkan hasil analisis validasi untuk tiap-tiap indikator validasi setiap pertemuan yang dinilai oleh validator. Berdasarkan pada tabel 1 mengenai hasil analisis validasi RPP dari seluruh validator dan seluruh pertemuan yaitu dari pertemuan pertama hingga pertemuan keempat, diperoleh hasil rata-rata 91,94\%. Dari hasil tersebut diperoleh indikator validasi RPP yang mendapat nilai validasi tertinggi yaitu pada indikator kesesuain rumusan masalah kompetensi dasar dengan silabus yang ada yang mana butir- butir validasi yang disajikan adalah kompetensi dasar pada RPP sesuai dengan silabus, dengan semua validator memberikan nilai 4 atau sangat baik pada indikator tersebut.

Hasil validasi Lembar Kerja Peserta Didik ((LKPD) yang dipaparkan pada tabel 4.2 mengenai hasil analisis validasi LKPD dari semua validator dan seluruh pertemuan didapatkan rata-rata 91,14\%. Pada setiap pertemuan diperoleh bahwa persentase semua validator adalah 91,14\%, hal ini dikarenakan setiap validator menceklis butir-butir validasi dengan nilai yang sama untuk semua pertemuan, meskipun para validator memiliki penilaian yang berbeda satu sama lain untuk tiap-tiap butir validasi. Salah satu faktor yang membuat hal tersebut adalah LKPD yang ditampilkan memiliki bentuk dan format yang hampir sama 
di setiap pertemuannya.

Berdasarkan hasil temuan penelitian diperoleh hasil pengembangan perangkat pembelajaran dengan menggunakan model Group Investigation (GI) pada materi bangun datar segiempat diperoleh hasil rata-rata penilaian validasi keempat validator untuk Rencana Pelaksanaan Pembelajaran (RPP) yaitu sebesar 91,94\% dengan kriteria sangat valid atau dapat digunakan tanpa revisi sedangkan nilai rata-rata Lembar Kerja Peserta Didik (LKPD) yaitu $91,14 \%$ yang mana memenuhi kriteria sangat valid. Sebelumnya pada saat proses validasi perangkat pembelajaran Rencana Pelaksanaan Pembelajaran (RPP) dan Lembar Kerja Peserta Didik (LKPD) peneliti melakukan 2 kali proses validasi kepada validator pertama dikarenakan hasil validasi perangkat pembelajaran Rencana Pelaksanaan Pembelajaran (RPP) dan Lembar Kerja Peserta Didik (LKPD) mendapat persentase yang sangat rendah sehingga peneliti kembali merevisi perangkat pembelajaran guna mendapat penilaian validasi yang baik.

Dari penjabaran di atas, dapat disimpulkan bahwa pengembangan perangkat pembelajaran dengan menggunakan model Group Investigation (GI) pada materi bangun datar segiempat menghasilkan perangkat pembelajaran berupa Rencana Pelaksanaan Pembelajaran (RPP) dan Lembar Kerja Peserta Didik (LKPD) yang valid dengan kategori yang sangat valid atau dapat digunakan tanpa perbaikan revisi. Dikatakan valid karena telah dilakukan validasi oleh validator.

Dalam penelitian ini memiliki kelemahan diantaranya: 1) Peneliti cukup sulit untuk menentukan sub-sub topik yang akan dipilih dari topik utama untuk materi bangun datar segiempat, 2) Membutuhkan waktu yang cukup lama untuk melakukan model Group Investigation (GI), 3) Perangkat pembelajaran yang peneliti kembangkan tidak dapat dilakukan uji coba lapangan, hal ini dikarenakan terjadinya pandemi virus Covid-19 sehingga peneliti tidak dapat mengetahui kepraktisan perangkat pembelajaran yang telah dikembangkan, 4)Lembar indikator validasi yang dilampirkan oleh peneliti tidak terlalu cocok menggunakan kategori penilaian skala likert.

\section{KESIMPULAN}

Berdasarkan hasil yang telah diuraikan pada bab 4 dapat disimpulkan bahwa dihasilkan perangkat pembelajaran dengan menggunakan model pembelajaran Group Investigation (GI) pada materi bangun datar segiempat yaitu Rencana Pelaksanaan Pembelajaran (RPP) dan Lembar Kerja Peserta Didik (LKPD) yang valid dengan RPP memperoleh nilai rata-rata adalah $91,94 \%$ sedangkan nilai rata-rata LKPD adalah $91,14 \%$ 
yang mana memenuhi kriteria sangat valid.

\section{UCAPAN TERIMAKASIH}

Yang pertama penulis ucapkan syukur Alhamdulillah segala puji bagi Allah SWT atas limpahan rahmat dan karunia serta Nikmat-Nya yang telah memberikan kesehatan kepada penulis sehingga terselesaikannya artikel jurnal ini. Dan tak lupa pula ucapkan shalawat serta salam kepada Baginda Rosul Nabi Besar Muhammad SAW, keluarga, sahabat dan orang-orang yang selalu teguh di jalan Allah SWT

Penulis menyadari bahwa dalam penyusunan artikel jurnal ini tidak lepas adanya bimbingan, bantuan dan kerja sama dari berbagai pihak. Oleh karena itu dengan segenap kerendahan hati yang tulis dan ikhlas mengucapkan terimakasih kepada pihak-pihak yang terlibat langsung maupun tidak langsung dalam penyusunan artikel jurnal ini.

\section{REFERENSI}

Alvionita, E., Abdurrahman, A., \& Herlina, S. (2019). Pengembangan Perangkat Pembelajaran Matematika dengan Model Guided Discovery Learning pada Materi Barisan dan Deret untuk Siswa Kelas X SMK. AKSIOMATIK: Jurnal Penelitian Pendidikan dan Pembelajaran Matematika, 7(1), 48-55.

Anggreini, E., Zulkarnain, Z., \& Ariawan, R. (2019). Pengembangan Perangkat Pembelajaran dengan Problem Based Learning Pada Materi Sistem Persamaan Liniear Tiga Variabel di Kelas X SMK Yabri Terpadu Pekanbaru. AKSIOMATIK: Jurnal Penelitian Pendidikan dan Pembelajaran Matematika, 7(1), 35-40.

Ariawan, R., \& Putri, K. J. (2020). Pengembangan Perangkat Pembelajaran Matematika dengan Model Pembelajaran Problem Based Learning Disertai Pendekatan Visual Thinking Pada Pokok Bahasan Kubus dan Balok Kelas VIII. JURING (Journal for Research in Mathematics Learning), 3(3), 293-302.

Hartono, A \& Pramukantoro, J. A. (2013). Pengembangan Perangkat Pembelajaran dengan Metode Pembelajaran Kooperatif GI (Group Investigation) pada Standar Kompetensi Memperbaiki CD Player di SMK Negeri 2 Surabaya. Jurnal Pendidikan Teknik Elektro, 2(2), 653-659.

Iqbal, M. 2017. Pengembangan Lembar Kerja Peserta Didik (LKPD) dengan Pendekatan Kontekstual Ditinjau dari Pemahaman Konsep dan Disposisi Matematis (Tesis, Program Studi Pascasarjana Magister Pendidikan Matematika Fakultas Keguruan dan Ilmu Pendidikan, Universitass Lampung, Bandar Lampung).

Komalasari, K. (2014). Pembelajaran Kontekstual Konsep dan Aplikasi. Bandung: PT Refika Aditama.

PP. Nomor 32 Tahun 2013 Tentang Standar Nasional Pendidikan. Jakarta.

Putri, M. T., Setyawan, A. A., \& Effendi, L. A. (2019). Pengembangan Perangkat Pembelajaran Berbasi Budaya Melayu Riau dengan Pendekatan Matematika Realistik di SD Negeri 013 Rengat Barat Tahun Ajaran 2017/2018. AKSIOMATIK: Jurnal Penelitian Pendidikan dan Pembelajaran Matematika, 7(1), 79-86.

Sadat, A., Harisuddin, M. I., \& Oktavian, I. (2019). Pembelajaran Matematika dengan Menggunakan Pendekatan Open-Ended untuk Meningkatkan Kemampuan 
Berfikir Kreatif Siswa. Symmetry: Pasundan Journal of Research in Mathematics Learning and Education, 5(2), 159-168.

Septiawan, B \& S. Sondang, M. (2013). Pengembangan Perangkat Pembelajaran Metode Group Investigation dengan Strategi Organisasi pada Standar Kompetensi Memperbaiki Radio Penerima di SMK Negeri 2 Surabaya. Jurnal Pendidikan Teknik Elektro, 2(1), 285-293.

Setyosari, P. (2013). Metode Penelitian Pendidikan dan Pengembangan. Jakarta: Kencana Prenada Media Group.

Suripah, S., \& Sthephani, A. (2017). Kemampuan berpikir kreatif matematis mahasiswa dalam menyelesaikan akar pangkat persamaan kompleks berdasarkan tingkat kemampuan akademik. Pythagoras: Jurnal Pendidikan Matematika, 12(2), 149160. 